\title{
Studi Dasar Posibilitas Pemanfaatan Bubuk Silika dari Batuan Alam Lokal LAPINDO sebagai Bahan Tambahan Semen
}

\author{
Widhya B., ${ }^{*}$ Suryadi, W. Firmansyah., Wahyu B.W, Alfian N., M. I. Amal, Agus S.W., dan Nurul T.R. \\ Lab Material Lanjut dan Nanoteknologi, Pusat Penelitian Fisika- LIPI Kawasan PUSPIPTEK Serpong Tangerang 15314
}

\begin{abstract}
Intisari
Bubuk silika telah diketahui banyak digunakan sebagai bahan penguat beton. Sementara itu, Indonesia kaya akan batuan alam yang mengandung silika. Dewasa ini, Lumpur Lapindo jumlahnya melimpah sekitar 480 hektar yang kandungannya kaya silika. Oleh karena itu, dilakukan studi dasar posibilitas pemanfaatan bubuk silika dari batuan lokal dan Lumpur Lapindo sebagai bahan tambahan semen. Batuan silika dihancurkan selama satu jam dan Lumpur Lapindo dikeringkan juga terlebih dahulu kemudian dihancurkan dengan milling selama satu jam. Bubuk hasil dicampur dengan Semen Gresik dan Semen Tiga Roda dengan substitusi 10\% dan $20 \%$ terhadap semen, selanjutnya dijadikan adonan semen dengan rasio air $1 / 3$ terhadap total campuran dan dicetak dengan bentuk silinder berdiameter $2 \mathrm{~cm}$ dan tinggi rata-rata $5 \mathrm{~cm}$. Hasilnya diuji tekan dengan UTM (Universal Test Machine) terhadap usia semen. Hasil uji tekan pada usia 91 hari menunjukkan bahwa semen dengan bubuk silika baik dari campuran sillika Kalimantan Putih dengan komposisi $20 \%$ bubuk silika dan $80 \%$ semen Gresik dengan penguatan 50\% dibandingkan dengan standar. Sedangkan untuk Lumpur Lapindo dengan penambahan $10 \%$ pada Semen Gresik memberikan hasil yang hampir sama dengan standar dan pencampuran Lumpur Lapindo dengan Semen Tiga Roda tidak memberikan hasil yang signifikan. Dengan demikian, Lumpur Lapindo dan Batu silika Kalimantan Putih memiliki posibilitas sebagai bahan tambahan Semen Gresik.
\end{abstract}

KATA KUNCI: semen, bubuk silika, batuan alam, Lumpur Lapindo, kuat tekan

I. PENDAHULUAN

Semburan Lumpur panas di Porong, Sidoarjo, hingga saat ini masih belum berhasil diantisipasi. Sementara itu, tercatat kerugian akibat semburan dan luapan Lumpur Lapindo Brantas mencapai Rp. 7,6 triliun [1]. Sedikitnya 4 desa atau sekitar 480 hektar lahan telah tergenang luapan Lumpur tersebut [2]. Jumlah lumpur yang sangat banyak dan kaya kandungan silika memiliki potensi untuk dimanfaatkan sebagai bahan tambahan semen, agar didapatkan kualitas semen yang lebih baik.

Penggunaan silika (khususnya mikrosilika) sebagai zat aditif sebenarnya sudah banyak dikembangkan dan diterapkan dalam industri semen [3]), namun demikian, harga mikrosilika sangat mahal, yaitu mencapai 10 kali harga semen, dan selama ini pemenuhan kebutuhan mikrosilika di Indonesia dipenuhi dengan impor. Sementara itu, di Indonesia terdapat batuan silika yang melimpah, yang tersebar di seluruh Indonesia. Sehingga jika ada teknologi yang dapat mengubah bahan baku silika alam ini, diharapkan dapat mengantikan peran mikrosilika. Oleh karena itu, dalam penelitian ini dilakukan Studi Dasar Posibilitas Pemanfaatan Bubuk Silika dari Batuan Alam Lokal dan Lumpur Lapindo sebagai bahan Tambahan Semen.

*E-MAIL: widhya_budiawan@yahoo.com
II. METODOLOGI PENELITIAN

Bahan yang digunakan dalam penelitian ini adalah Lumpur Lapindo yang telah dikeringkan dan dimilling selama satu jam. Selain itu juga digunakan batu alam silika dari Kalimantan dan Lampung yang juga dimilling selama satu jam. Bubuk yang dihasilkan seperti yang terlihat pada Gambar 1 .

Bubuk hasil milling dicampur dengan Semen Gresik dan Semen Tiga Roda dengan substitusi $10 \%$ dan $20 \%$ terhadap

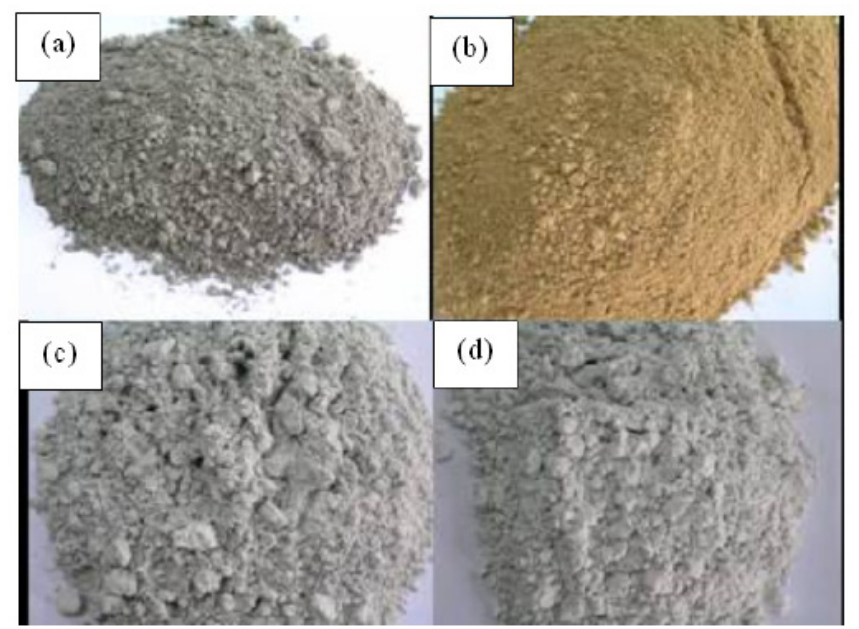

Gambar 1: Bubuk hasil milling (a) Lumpur Lapindo (b) Kalimantan Kuning (c) Kalimantan Putih (d) Lampung 
semen, selanjutnya dijadikan adonan semen dengan rasio air $1 / 3$ terhadap total campuran dan dicetak dengan bentuk silinder berdiameter $2 \mathrm{~cm}$ dan tinggi rata-rata $5 \mathrm{~cm}$. Cetakan dikeringkan dengan didiamkan dalam kondisi suhu ruang selama 24 jam. Selanjutnya hasil cetakan direndam dalam air untuk mendapatkan kelembaban yang seragam dan diuji tekan dengan UTM (Universal Test Machine) dengan usia yang bervariasi. Bagan langkah kerja dari penelitian ini sebagaimana ditunjukkan pada Gambar 2. Guna mempermudah dalam pembahasan maka digunakan kode-kode seperti ditunjukkan pada Tabel 1.

TABEL I: Keterangan kode dan komposisi

\begin{tabular}{|c|c|}
\hline Komposisi & Kode \\
\hline Semen Gresik murni $(100 \%)$ & SG100 \\
\hline Semen Tiga Roda murni $(100 \%)$ & $3 \mathrm{R} 100$ \\
\hline Semen Gresik $80 \%$ silika Kalimantan Kuning $20 \%$ & SG8KK2 \\
\hline Semen Gresik $80 \%$ silika Kalimantan Putih $20 \%$ & SG8KP2 \\
\hline Semen Gresik $80 \%$ silika Lampung $20 \%$ & SG8LP2 \\
\hline Semen Gresik $80 \%$ Lumpur Lapindo $20 \%$ & SG8LAPIN2 \\
\hline Semen Gresik $90 \%$ silika Kalimantan Kuning $10 \%$ & SG9KK1 \\
\hline Semen Gresik $90 \%$ silika Kalimantan Putih $10 \%$ & SG9KP1 \\
\hline Semen Gresik 90\% silika Lampung $10 \%$ & SG9LP1 \\
\hline Semen Gresik 90\% Lumpur Lapindo $10 \%$ & SG9LAPIN1 \\
\hline Semen Tiga Roda $80 \%$ silika Kalimantan Kuning $20 \%$ & 3R8KK2 \\
\hline Semen Tiga Roda $80 \%$ silika Kalimantan Putih $20 \%$ & 3R8KP2 \\
\hline Semen Tiga Roda $80 \%$ silika Lampung $20 \%$ & 3R8LP2 \\
\hline Semen Tiga Roda $80 \%$ Lumpur Lapindo $20 \%$ & 3R8LAPIN2 \\
\hline Semen Tiga Roda $90 \%$ silika Kalimantan Kuning $10 \%$ & 3R9KK1 \\
\hline Semen Tiga Roda $90 \%$ silika Kalimantan Putih $10 \%$ & 3R9KP1 \\
\hline Semen Tiga Roda $90 \%$ silika Lampung $10 \%$ & 3R9LP1 \\
\hline Semen Tiga Roda 90\% Lumpur Lapindo 10\% & 3R9LAPIN1 \\
\hline
\end{tabular}

\section{HASIL DAN DISKUSI}

Gambar 3 menunjukkan kuat tekan Semen Gresik dengan variasi campuran bubuk silika dan Lumpur Lapindo. Pada tahap awal pengerasan (ketika umur semen mencapai 28 hari), penambahan bubuk silika Lampung dan Lumpur Lapindo 20 $\%$ pada Semen Gresik secara drastis menurunkan kuat tekan sampai sekitar $40 \%$ dari sampel standard (lihat Gambar 3 (a)). Sementara itu, ketika umur semen mencapai 90 hari, kuat tekan Semen Gresik standard menurun dan penambahan bubuk silika dapat meningkatkan kuat tekannya sampai $25-40 \%$ melebihi kuat tekan standard. Pada penambahan 10 $\%$, Kuat tekan Semen Gresik-Lumpur Lapindo (SG9LAPIN1) sedikit di atas standard pada tahap awal pengerasan sampai 28 hari (lihat Gambar 3 (b)). Sementara itu, Semen Gresik dengan penambahan bubuk silika berada dibawah standard. Namun, ketika umur semen mencapai 91 hari, kuat tekan dengan penambahan baik silika ataupun Lumpur Lapindo berada di atas standard. Bahkan, kuat tekan Semen Gresik dengan penambahan silika Kalimantan putih meningkat hampir $50 \%$ dari standard. Gambar 4 menunjukkan kuat tekan

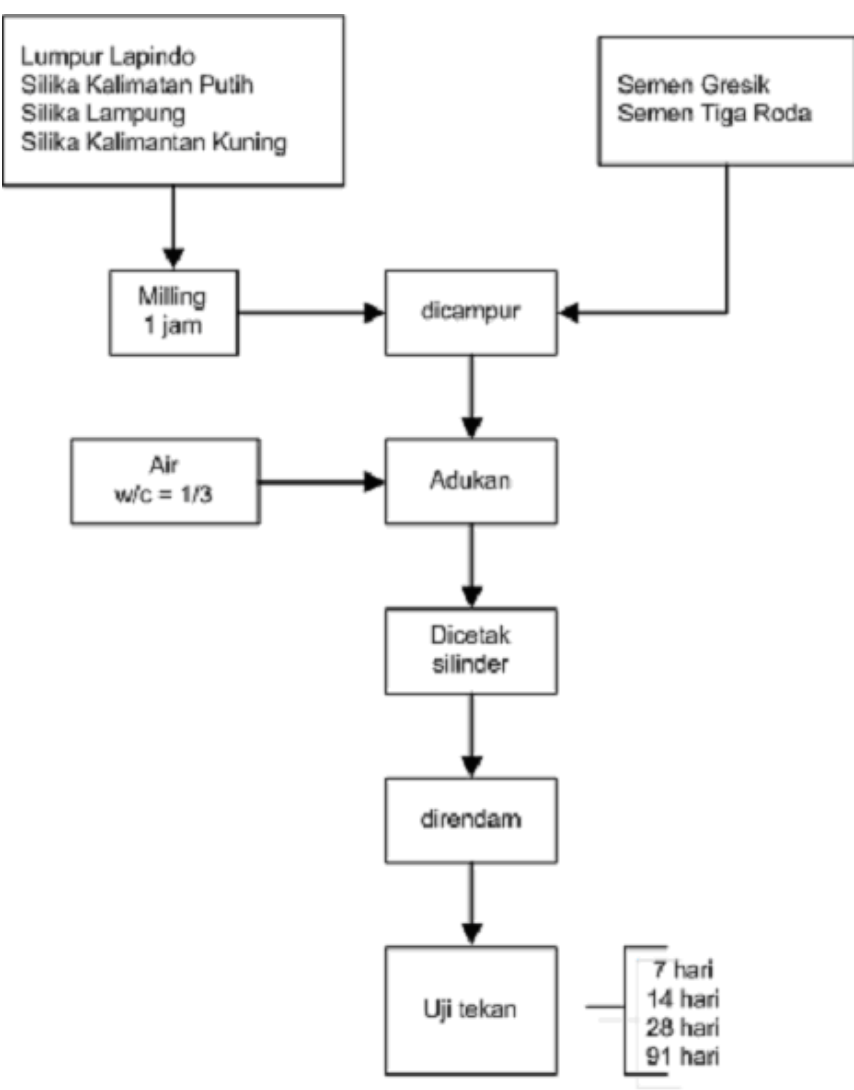

Gambar 2: Bagan langkah kerja percobaan

Semen 3 Roda dengan variasi campuran bubuk silika dan Lumpur Lapindo. Pada penambahan $20 \%$, kuat tekan Semen 3 Roda-Lumpur Lapindo (3R8LPIN2) berada di bawah sekitar $20 \%$ dari standard. Sementara itu, penambahan bubuk silika menunjukkan peningkatan kuat tekan 20 - 50\% dari nilai standard. Pada penambahan $10 \%$, penurunan kuat tekan dengan penambahan Lumpur Lapindo dan peningkatan kuat tekan dengan penambahan silika memiliki kecenderungan yang sama dengan kuat tekan dengan penambahan $20 \%$. Penambahan Lumpur Lapindo 10 dan $20 \%$ pada Semen 3 Roda akan mengurangi kuat tekan hingga $20 \%$, sementara itu penambahan bubuk silika dapat meningkatkan kuat tekan hingga mencapai $20-40 \%$.

Gambar 5 menunjukkan foto pecahan Semen Gresik dengan penambahan bubuk silika Kalimantan putih $10 \%$ (SG9KP1) dengan kekuatan maksimal $59 \mathrm{MPa}$ dan pecahan Semen 3 Roda dengan penambahan Lumpur Lapindo $10 \%$ (3R9LPIN1) dengan kekuatan minimum 34 MPa setelah berumur 91 hari. Sementara itu Gambar 5 menunjukkan mikrostruktur kedua sampel tersebut. Dari Gambar 5 (a) terlihat bahwa pecahan sampel SG9KP1 banyak berbentuk serpihan yang memanjang menunjukkan bahwa pengerasan pasta semen berjalan dengan baik. Terlihat bahwa mikrostruktur SG9KP1 terdiri dari partikel-partikel kecil yang rata di seluruh bagian yang memungkinkan kerapatannya atau densitasnya lebih sempurna. Oleh karena itu, kuat tekan SG9KP1 mencapai maksimal (59 $\mathrm{MPa})$. Sementara itu, pecahan 
(a)

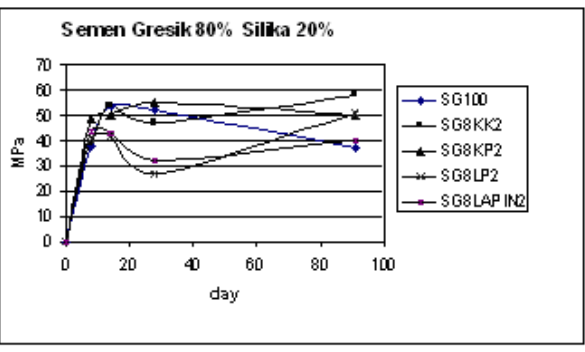

(b)

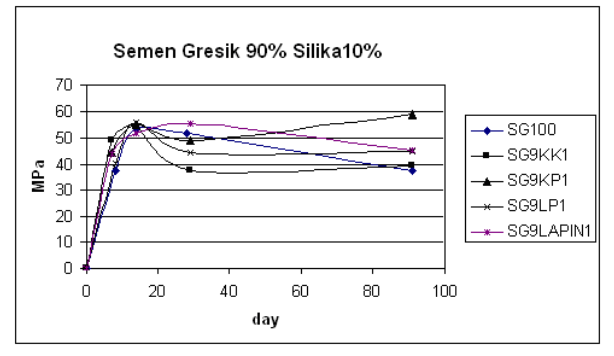

Gambar 3: (a) Semen Gresik $80 \%$ Silika $20 \%$ dan (b) Semen Gresik $90 \%$ Silika $10 \%$.

(a)

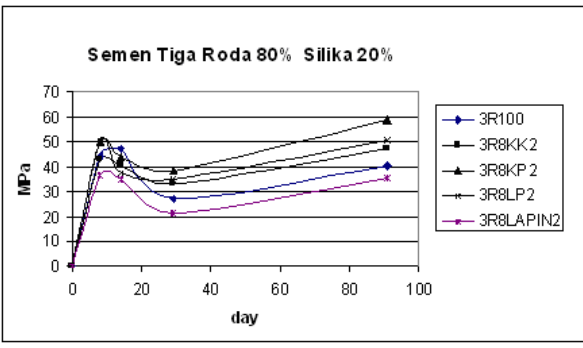

(b)

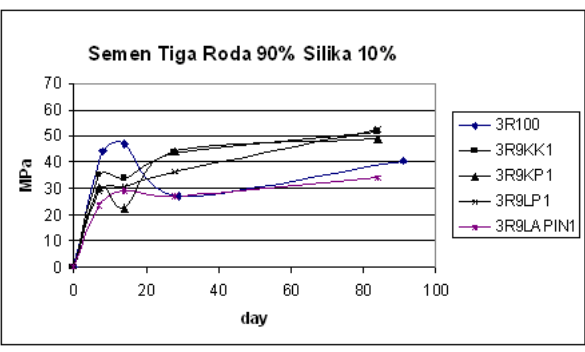

Gambar 4: (a) Semen Tiga Roda $80 \%$ Silika 20\% dan (b) Semen Tiga Roda $90 \%$ Silika $10 \%$.

sampel 3R9LPIN1 berbentuk potongan-potogan yang tumpul dan banyak partikel halus. Hal ini menunjukkan bahwa pengerasan pasta semen pada 3R9LPIN1 belum optimum berjalan. Sementara itu mikrostruktur 3R9LPIN1 mengandung void yang mengakibatkan penurunan kerapatan atau densitasnya, sehingga kuat tekan 3R9LPIN1 jauh di bawah standard yaitu hanya $34 \mathrm{MPa}$.

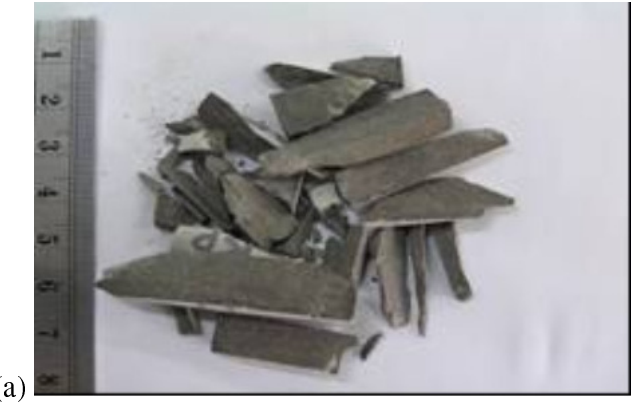

(b)

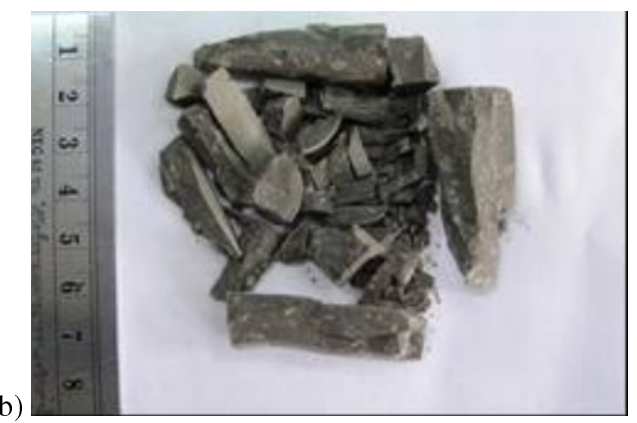

Gambar 5: Pecahan (a) Semen Gresik 90\% Kalimantn Putih 10\% dan (b) Semen Tiga Roda 90\% Lumpur Lapindo 10\%.

(a)

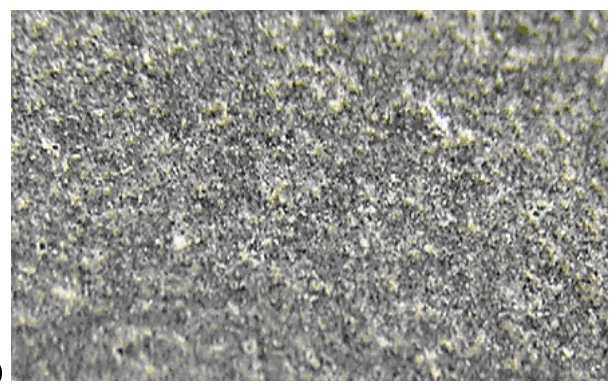

(b)

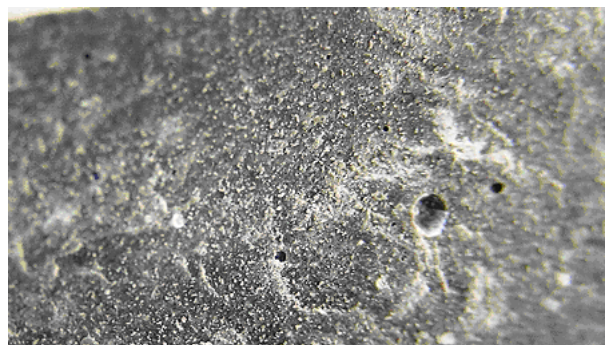

Gambar 6: Mikrostruktur (a) Semen Gresik 90\% Kalimantan Putih $10 \%$ dan (b) Semen Tiga Roda $90 \%$ Lapindo $10 \%$.

\section{SIMPULAN}

1. Bubuk silika dari batuan alami lokal dapat meningkatkan kuat tekan semen, baik Semen Gresik maupun Semen Tiga Roda hingga penguatan $40 \%$

2. Penambahan Lumpur Lapindo pada Semen Tiga Roda menurunkan kekuatan hingga $10 \%$, sedangkan penam- 
bahan Lumpur Lapindo pada Semen Tiga Roda memiliki kekuatan yang sama dengan standar

3. Batuan silika dari batuan alami lokal dapat digunakan sebagai bahan penguat semen dan Lumpur Lapindo memungkinkan untuk dijadikan sebagai bahan tambahan khusus untuk Semen Gresik.
[1] Kompas, 5 Maret 2007, Kerugian akibat lumpur lapindo Rp. 7,6 triliun. www.kompas.com

[2] Metro TV News, 12 Maret 2007, Todays Dialogue, www.metrotvnews.com

[3] Malhotra , Fly Ash, Silica Fume, Slag, and Natural Pozolans in
Concrete, American Concrete Institute, Detroit (1989)

[4] Shetty, M.S., Concrete Technology Theory and Practice, S Chand \& Compnay Ltd. New Delhi (1982) 